\title{
Intermédialités
}

Histoire et théorie des arts, des lettres et des techniques

Intermediality

History and Theory of the Arts, Literature and Technologies

\section{Introduction. Rendering Time (Basinski)}

\section{Charlotte Brady-Savignac}

Numéro 33, printemps 2019

restituer (le temps)

rendering (time)

URI : https://id.erudit.org/iderudit/1065022ar

DOI : https://doi.org/10.7202/1065022ar

Aller au sommaire du numéro

Éditeur(s)

Revue intermédialités

ISSN

1920-3136 (numérique)

Découvrir la revue

Citer ce document

Brady-Savignac, C. (2019). Introduction. Rendering Time (Basinski).

Intermédialités / Intermediality, (33). https://doi.org/10.7202/1065022ar d'utilisation que vous pouvez consulter en ligne. 


\title{
Rendering Time (Basinski)
}

\author{
Charlotte Brady-Savignac
}

T

rained as a classical clarinetist, William Basinski (born in 1958) draws inspiration for his compositions from avant-garde and minimalist practices, such as John Cage's idea of "chance operations," Brian Eno's drone music, and Steve Reich's tape loops. Using quarter-inch tape for his compositions since the late 70's with the vast archive he built, he now includes the necessary digital tools when they are required. Basinski develops short, a few seconds long, musical loops that stretch up to an hour in duration through various analog or digital processing, and that are underpinned by his fascination with urban and daily sound sources: motors, horns, sirens, refrigeration compressors, elevator music, radio channels. It is with The Disintegration Loops (200I) that Basinski made his mark on the contemporary American art scene. Resulting from the digital transfer of the artist's magnetic tapes, the piece consists of a series of musical loops that reflect the gradual degradation of the tapes as they are reused. This work is the subject of two in-depth analyses in the articles of Kemper and Jackson in this issue of Intermédialités/Intermediality, dedicated to the theme of rendering time. More broadly, in its musical, performative, and audiovisual nature the artist's practice raises fascinating questions of remediation and remediatization. The following interview extends these analyses and addresses the technical, material, performative, and collaborative aspects of Basinski's practice. The interview is presented here in two formats: a transcript of the conversation, which took place via Skype on is April 2019 between Basinski and André Habib, professor at the University of Montreal and a scholar of the artist's work ${ }^{\mathrm{I}}$, and a sound montage of excerpts from this conversation.

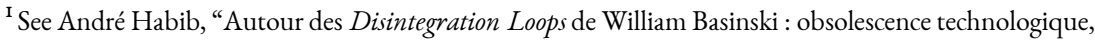
ruines et les paradoxes de la commémoration," in the proceedings of the conference Arts et Médias, "Paraître et disparaître : l’art et ses objets perdus," 5-6 November 20I5, Université de Montréal, Montreal,
} 
On the one hand, the curious reader will find in the transcribed version many details that contextualize the musician's practice from the perspective of the techniques and technologies employed, as well as references that situate Basinski's work within an international group of collaborators. On the other hand, the selection and editing of sound excerpts not only reveals the texture and rhythm of Basinski's voice and proposes a glimpse at the diversity and plasticity of his work, but also highlights some elements found in intermedial studies, namely, an attention to form (the loop as a temporal form), medium, and performance. While listening to these sound fragments, which come mostly from The Disintegration Loops and from Basinski's latest album On Time out of Time (2019) and which accompany and punctuate the artist's voice and emphasize his intonations, modulations, hesitations, and silences, we rediscover the singularity of practice, both sensory and meditative...

QC; https://www.colloqueartsmedias.ca/actes/2015/autour-des-disintegration-loops-dewilliam-basinski (accessed II September 2019). 